Kull, CA (2016) Bushfire in Madagascar: natural hazard, useful tool, and change agent. pp. 143-167 in Natural Hazards and Peoples in the Indian Ocean World: Bordering on Danger, edited by Bankoff, G \& J Christensen: Palgrave Macmillan.

\author{
Author's version. May be posted to online repository after 36 month embargo. \\ Courtesy of Palgrave Macmillan.
}

\title{
3. Bushfire in Madagascar: natural hazard, useful tool, and change agent
}

\author{
Christian A. Kull
}

\section{Introduction}

The island of Madagascar can be a dangerous place. It lies directly in the pathway of many Indian Ocean tropical cyclones, which regularly devastate one part or the other of the island, flooding settlements and crop fields, tearing roofs off houses, and interrupting road, rail, electricity, and communications networks. Weather patterns provide further hazards, including floods and droughts, both particularly stressful to a population largely dependent on food and income from the land. The island is also no stranger to epidemics - cholera recurred recently; plague is still present - and locusts swarm out of the southwest every decade or so, devastating crops and pastures. And of course, the hazards of poverty and political strife make life challenging for all. ${ }^{1}$

Bushfire does not usually figure on lists of natural hazards and disasters in Madagascar, despite being an 'Isle of Fire'. ${ }^{2}$ This is quite a contrast to other parts of the world particularly Australia, California, and the Mediterranean rim - where bushfire is one of the most high profile hazards. Fire on Madagascar is usually written about as a 'hazard for nature', not as a 'natural hazard' for humans. This is because it is the proximate cause of much habitat loss and deforestation on an island with a rare, endemic, and threatened flora and fauna.

Madagascar is prone to bushfire because most of the island is neither too wet, nor too dry to burn. A generous wet season drops an average $1,500 \mathrm{~mm}$ of rain on much of the island between December and March, promoting rapid vegetation growth. This is typically followed by a long dry season of six to eight months. If, by October, people have not burnt the dry grasses, lightning from convective thunderstorms ahead of the wet season may provide the spark. In my previous work, I showed that in this fire-prone landscape, farmers and herders harness fire to achieve a variety of land and vegetation management goals - from pasture renewal and fuel management to field clearance and pest control. This parallels peoples' reliance on fire for diverse uses around the Indian Ocean, whether in Indonesia, Western Australia, or Africa. ${ }^{3}$ I also showed how these local practices have long clashed with the antifire views and policies of government officials, foresters, and conservationists, leading to tensions and illicit burning. Again, such tensions are paralleled around the Indian Ocean. ${ }^{4}$

However, largely unexplored in these accounts is the fact that fire can be hazardous to humans and their property. On the Great Red Island, people's homes - with their thatched roofs, and in coastal areas with thatched walls - are particularly susceptible and frequently go up in flames. Norwegian missionary Johan Einrem tells of often hearing of houses or villages that burned, even of drunken Sakalava villagers partying as their hamlet burned. ${ }^{5}$ In 1969 , 
eight houses were ravaged in villages in the commune of Analalava. ${ }^{6}$ Just recently, in June 2013,51 houses in the village of Tsaratanàna in the Vohémar region burned catastrophically. ${ }^{7}$ Many of the more dramatic fires that destroy houses and buildings are domestic, or urban, fires, not bushfires. A kitchen fire, for instance, allegedly caused the 2013 village inferno mentioned above. Yet bushfires do affect houses, often by 'spotting', that is, by burning embers lifted by the hot air only to land on flammable rooftops. According to official statistics from the Forest Service, in 1968 bushfires in Madagascar destroyed $16.6 \mathrm{~km}^{2}$ of forest plantations, $38 \mathrm{~km}^{2}$ of natural forests, 236 houses, 52 granaries, two churches, two government farms, 6,000 tons of cotton, one hectare of vineyards, 300 orange trees, and 3,000 pineapple plants; the fires also burned 283 people and caused one death. ${ }^{8}$

These hazards, while impressive, of course do not rival the disasters linked to specific cyclonic or drought events, but nonetheless fire can be a damaging hazard on the island. So why then is there little attention to fire as a hazard on the island? This chapter argues that the lack of attention to fire as a hazard comes from the fact that fire is multivalent, ambiguous, and flexible. It is both human and natural, it is both useful and problematic. Fire has multiple interpretations in rural landscapes. It is simultaneously an occasional 'hazard' for thatch-roof huts or crop fields; a 'useful tool' that farmers and pastoralists use to manage vegetation; and a major transformational force, or 'change agent', that damages land and forest.

The rest of this chapter builds a story of fire in Madagascar. In order to structure the narrative and analysis, it builds on the concept of pyric phases. ${ }^{9}$ This concept suggests that the human relationship with fire changes in tandem with transformations to our cultural, social, and economic systems. In Madagascar, we might identify six important pyric phases. First, natural biospheric fires characterized landscapes before humans began to set their own fires (and continued in remote areas until recently). A second pyric phase corresponds to the fires lit by hunter-gatherers that were presumably the first residents on the island (perhaps 4,000 years ago, continuing until recently in some areas). After intensive periods of trans-Indian Ocean contact and migration, two new pyric phases appeared on the island linked to agriculturalists (ca. 1,500 years ago to present) and pastoralists (ca. 1,100 years ago to present). The fifth and sixth pyric phases correspond with attempts to control fire in the context of colonial and postcolonial governance. These phases are associated with the goal of a modern, industrial economy (ca. 1900 to present) and efforts towards nature conservation (1920s to present). These phases are sequential yet also concurrent, particularly for the latter four categories which are all present in different parts of the landscape today. In each pyric phase, fire serves, or is perceived to serve, different roles as hazard, tool, or change agent. What follows thus traces fire in Madagascar through these pyric phases, emphasizing the different role of fire in each phase, and telling some of the historical story of how governments have sought to manage the complex phenomenon of fire. ${ }^{10}$ 


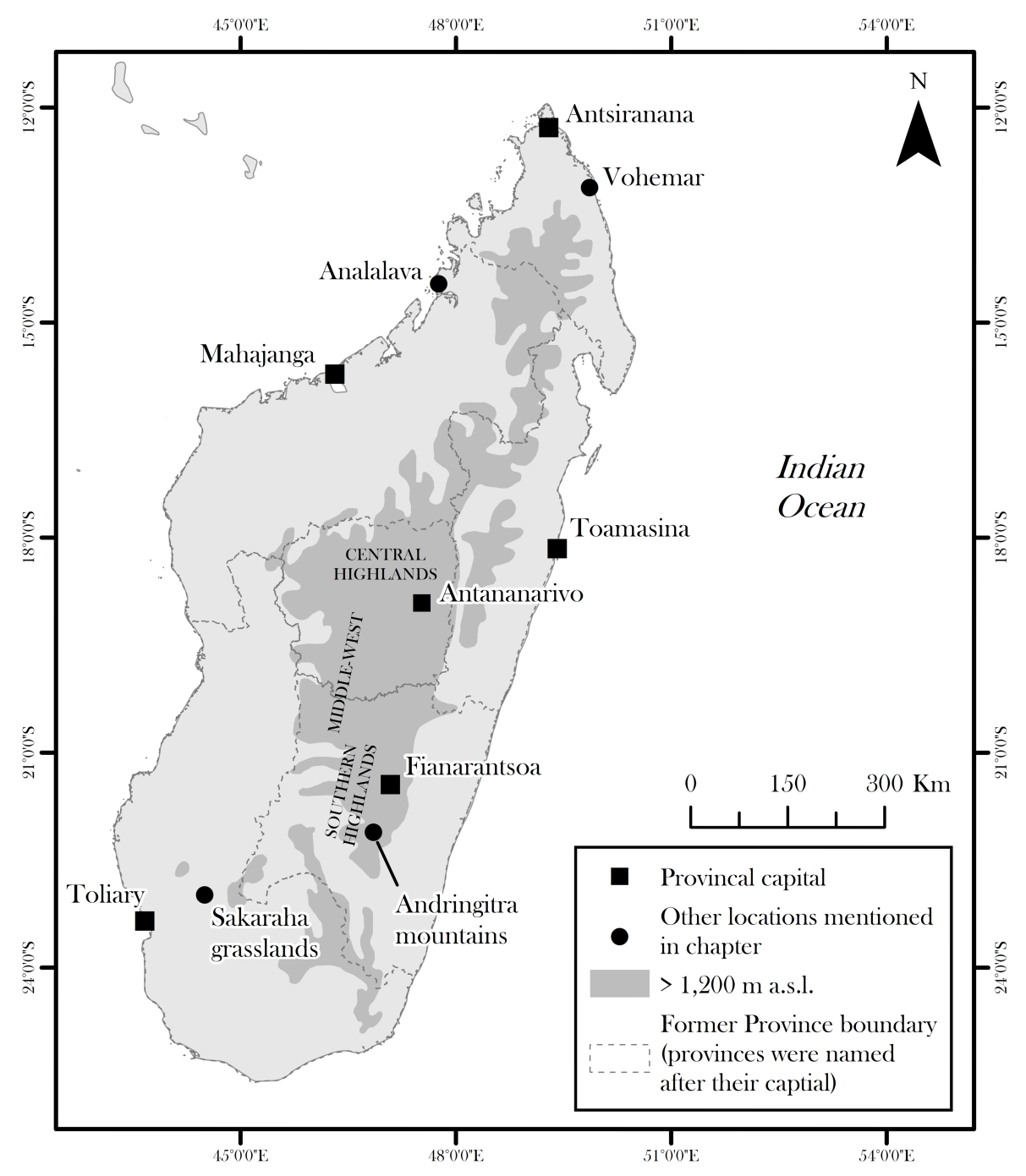

Figure 3.1. Madagascar, showing locations mentioned in chapter.

\section{Biospheric fire before the first humans}

Before humans arrived on the island, there were, for lack of a better term, natural biospheric fires. These fires were not a hazard nor were they tools, at least not in the anthropogenic sense in which these terms are usually used, for there were no humans. They were, however, change agents, processes crucial to the maintenance and transformation of the vegetation cover of the island. Palaeoecological research suggests that pre-human Madagascar was characterized by a mosaic of forests, woodlands, savannas, and heath, shifting in response to climatic swings. Fire is evident throughout the sediment core record, presumably lit by lightning as well as - in certain regions and time periods - by volcanic activity. The specific composition and distribution of vegetation types, shaped in the shorter term by fire, grazing megafauna (like large lemurs, elephant birds, and pigmy hippopotamuses), and periodic cyclones, changed over the longer term in response to fluctuating climate conditions. ${ }^{11}$ Fires possibly burned quite big when they did burn, due to fuel build-up between lightning strikes. One could argue that such 'natural' fires characterizing this pyric phase persisted for many centuries after human settlement, in areas such as mountaintops remote from human influence. Lightning strikes continue to this day, though they touch down mostly in vegetation already shaped through anthropogenic influences. 


\section{Foraging fires (c.4,000 years ago to recent)}

The early settlement of Madagascar is a contentious topic, but several recent archaeological finds suggest the possibility of people hunting and gathering on the island as far as 4000 years ago. ${ }^{12}$ The details of their arrival and subsequent movements aside, it is unquestioned that people with a foraging lifestyle have - at different times and places - occupied the island. These could be the hypothesized early arrivals in the research cited above, the semi-mythical 'vazimba' who preceded the rice-farming Indonesians in the highlands, or the Mikea who persist to this day as a cultural group in south western forests. People living with a subsistence foraging lifestyle would have been associated with a particular pyric phase, what David Bowman and colleagues called 'wildland anthropogenic fire'. ${ }^{13}$ Like hunter-gatherer cultures elsewhere around the world - Australian aborigines being a primary example ${ }^{14}$ - they would have used, shepherded, and lit fires to manage habitats to favour certain habitats, certain plants, certain game animals. Fire would have been a tool. But it would also have been a hazard, one suspects, in terms of damage to shelters, food stocks, life and limb. Finally, from an environmental perspective, foraging fires would have been a change agent, with more frequent fires, probably in different seasons, leading to sometimes subtle, sometimes major alterations in previous 'natural' vegetation cover.

\section{Agricultural fires (c.1500 years ago to present)}

The earliest archaeological evidence of fixed settlements and associated farming activities dates back to 500-700 CE, with both African and Indonesian heritage. ${ }^{15}$ The spread of agriculture on the island heralded a new pyric phase, 'agricultural anthropogenic fire' in the terms of Bowman and colleagues. This phase is visible in the palaeoecological and archaeological records, which, in the central highlands for instance, suggest a ten-fold increase in fires from previous levels between 600 and $800 \mathrm{CE}$, and show evidence of cultivated crops and permanent settlements from ca. $1000 \mathrm{CE}$, with grasses replacing woody vegetation across the landscape. A second wave of settlement took place early in the Second Millennium, arriving, it is thought, in successive waves of colonization from present-day Indonesia. By the thirteenth and fourteenth centuries, evidence of their well-established villages is widespread. These settlers found a largely grass-dominated landscape, which they maintained through fire and grazing; they also introduced irrigated rice-based agriculture to the floodplains and valleys. Over time, centralized political structures emerged in a number of highland river valleys. ${ }^{16}$

In the agricultural pyric phase, fire is very clearly used as a tool, primarily to clear fallow fields or forest patches for cultivation, but also as a means of wildfire prevention, pest control, and fertilization. Fire's use in agriculture in Madagascar parallels similar uses in traditional farming systems around the world. ${ }^{17}$ Crop fires tend to be smaller in extent than pasture fires, but relatively numerous. In grassland zones, people burn the standing vegetation in the plot they intend to cultivate - it may be uncultivated grassland, long-fallow fields covered with grass, ferns or bushes, or short fallows with crop stubble. After burning, a team of two or three farmers labours with spades to prepare the soil for cultivation. Sometimes, farmers collect additional fuel to burn in their fields - cut grass, rice straw, scrub. Other fires include those used to 'clean' field edges and canals, facilitating travel, water flow, and pest control. In more humid forest zones, 'slash-and-burn' or shifting cultivation is more common, usually called tavy in Madagascar. Farmers choose a plot - usually an overgrown long-fallow field called savoka, secondary forest, or more rarely today, in primary forest. They cut the standing vegetation, let it dry for a few weeks, prepare a fire break, then set fire just before the rainy season, typically in October or November. The plot is then cultivated with rainfed rice and other crops for one or more years before being allowed to fallow. Farmers perceive fire-as-a- 
tool to be an integral part of the agricultural system. ${ }^{18}$

As useful as they are, fires in this pyric phase can also be hazards. A poorly mastered fire can, given the right conditions, damage life and property. In farming areas, it is possible to lose not just food stores, but also standing crops to fire. ${ }^{19}$ Most dramatically, perhaps, certain agricultural fires are important change agents. Fire is used as the proximate tool, after all, to render an area of forest, bush, or grassland cultivable. Thus fire is associated with the advancing agricultural frontier, particularly in the forest zones that encircle the island. Repeated cycles of agricultural fire for subsistence and cash crops are the proximate cause of the replacement of native forests with farm-, bush-, and grassland. ${ }^{20}$ There are even legends in Madagascar of a 'great fire', or afotroa, that is associated with forest clearance during the original settlement. ${ }^{21}$

\section{Pastoral fires (c.1100 years ago to present)}

The earliest evidence of a proliferation of zebu cattle on the island dates to around the tenth century, in the northwest, with expansion to the central highlands within a century or two. ${ }^{22}$ While most scholars assert that cattle were introduced from Africa, some hypothesize direct links to India. ${ }^{23}$ The expansion of a pastoral lifestyle heralded a 'pastoral pyric phase'. Pastoral fires continue to affect the largest surface area of any fires in Madagascar. These fires are used to manage grasslands used for extensive - that is, low density - grazing. Madagascar's cattle herds, limited by dry season forage resources, cannot keep up with the growth in rainy season grasses. People light fires to keep bushes from encroaching, to remove lignified dry grass, to encourage a 'green bite' of new sprouts, and to guard against fuel accumulation. ${ }^{24}$ When asked to justify pasture fires, herders I interviewed retorted 'what would the cattle eat without fire?' and stated that the fresh green shoots are needed 'mba voky ny omby - so that the cattle have eaten enough'. While walking through the hills with my informants, it was apparent that they appreciate a landscape kept free of bush encroachment and accumulated dry grass fuel, calling such a landscapes 'madio' or 'clean'. ${ }^{25}$

These useful fires are key tools in the pastoral economy. In the past, fires served to maintain and renew grassland resources. This was recognized by colonial district officers, as I report below. The colonial cattle industry relied on fires as well. Ranches in the Middle West burned their lands for pasture renewal, ${ }^{26}$ and cattle industry experts promoted the experience of South African ranchers with fire. ${ }^{27}$ Today, pasture fires continue to play an important role in the open spaces where herders maintain herds for subsistence and prestige ${ }^{28}$ as well as in more densely settled areas where mixed agropastoral economies dominate.

While these fires serve to manage fuel loads in landscapes where a highly productive rainy season is followed by a hot, dry season, they can also become hazards when they burn grass roofs, enclosures, or crop stores. And these fires are certainly change agents, expanding grassy land covers at the expense of woody ones. ${ }^{29}$ But the emphasis in this pyric phase is on fire as a useful tool.

\section{Fire suppression for a 'modern' economy (c.1900 to present)}

While the previous three pyric phases co-existed in the landscape for many centuries, the colonial period brought a new phase to Madagascar. During the 1800 s, a period in which the island became unified politically, a number of proclamations and rules addressed forest cutting and forest burning, yet they did not generally regulate crop field or grassland fires. ${ }^{30}$ The highlands and savannah zones of the west were characterized by a free-burning, pastureoriented fire regime. The landscape was dominated by endless grass-covered hills; trees only 
grew near hilltop villages. In eastern forest zones, tavy fires provided the rice upon which people depended for food.

From 1896, France colonized Madagascar. ${ }^{31}$ The French intended to establish a profitable economy linked to agricultural production and resource extraction, and their policies reflect that goal. They abolished slavery, developed transportation infrastructure, requisitioned rice from farmers, and established commercial crop (and later forest) plantations. While many officers and settlers recognized the utility of fire in certain circumstances, the emphasis was increasingly on fire exclusion. The advent of industrialization and modernity brought by colonialism led to increased use of internal combustion to replace what used to be done by fire (field clearance, fertilization) and gave the mechanical tools and ideological frameworks necessary to circumscribe fire. In this pyric phase, fire is only grudgingly seen as a tool, and instead is largely seen as a hazard, a threat to productive assets and resources (like timber, soils, and infrastructure). The change agent aspect of fire is less emphasized; this comes with a focus on conservation as I profile later.

During the first decade of French control, authorities focused on 'pacifying' the island and establishing administrative structures. Their approach to fire policy, marked by hesitation, centred on economic issues. The Forest Service's mission was to protect forests for 'rational' exploitation and to protect soils from degradation. ${ }^{32}$ Colonial district officers, faced with the difficult task of actually administering the island for economic profit and political stability, did not share the foresters' anti-fire enthusiasm.

In 1897, Governor Joseph Gallieni, ordered his officers to do their best to stop the damage done by fires and peasant cultivators to the forest. ${ }^{33}$ The Forestry Decree of 1900 banned dry season fires within 200 meters of forests, except by authorizations granted to private landowners (which thus excluded indigenous tavy cultivators). ${ }^{34}$ This proved unpopular. District officers wrote to the Governor that fires are critical to cattle husbandry, useful in controlling insects, rats and locusts, and are used from China to South Africa. ${ }^{35}$ As a result, Gallieni, recognizing that 'modern' techniques of mowing and haying were not yet realistic, re-authorized much grassland burning, but reiterated a strict ban on fires in forest. ${ }^{36}$

The tone of the following two decades was set by the primordial economic concerns of the colony. The central government's position against fire, especially tavy, hardened, as it sought to protect the logging industry and commercial agricultural plantations. Governors Victor Augagneur, Albert Picquié, and Hubert Garbit each sought to tighten the reins, issuing circulars to this effect in 1907, 1909, 1913, 1915, and 1920. However, district officers continued to defend peasant burning, and in a compromise the government 'temporarily' began to regulate and authorize burning until 'modern' agricultural and pastoral techniques could be introduced. ${ }^{37}$

In the meantime, the government increased its efforts to enforce the new regulations. Some fires burned into forests, tree plantations, or colonists' lands; others destroyed houses or entire villages. As a culprit could rarely be found, officers relied on collective fines. Enforcement was uneven. Burning continued, with or without all the detailed prescriptions of local fire regulations. Fire legislation remained largely non-functional, due to the number of exceptions, the weakness of the Forest Service, and the lack of will on the part of some authorities. ${ }^{38}$ The logic behind this modernist pyric phase continues to this day. Fire is repeatedly seen as antithetical and hazardous to a modern economy. However, from the 1920s, these ideas were complemented by those centred on nature conservation. 


\section{Fire suppression for nature conservation (1920s to present)}

A corollary of the modern, industrial pyric phase and its preference for fire exclusion is the 'protect nature' pyric phase. The environmental ravages of the industrial revolution were one of the reasons, after all, for the emergence of the modern conservation movement and its fundamentally modernist project of separating 'wild nature' from productive landscapes. Given that dominant ecological ideas in the twentieth century saw fire as antithetical to the conservation of wild nature, the conservation movement promoted fire suppression. In this pyric phase, fire is hardly seen as a tool, instead it is emphasized as a hazard, not for humans, but for wildlife and habitats. Most crucially, fire is seen as a change agent that lies behind the deforestation and degradation that threatens the island's natural resources.

This pyric phase appeared in Madagascar in the 1920s as a complement to the economic arguments outlined above. The tone of state-led fire repression stiffened from the mid-1920s into the 1940s. Naturalists concerned with the loss of forests gained an increasingly prominent role in policy-making. The number of district officials defending local fire practices shrunk significantly (through not completely). A key moment was the new Forest Decree, which appeared in January 1930 after a decade of consultation and debate. ${ }^{39}$

The 1930 Decree arose out of foresters' concerns with the pace of extractive logging, and naturalists' alarm over the loss of forest to fire. ${ }^{40}$ Prominent naturalists Henri Perrier de la Bâthie and Henri Humbert actively promoted the decree. ${ }^{41}$ Perrier believed that the Malagasy burn 'out of simple habit and without any reason'. Humbert's influential monograph is tellingly subtitled 'the destruction of an island flora by fire.' Louis Lavauden, who in 1928 became Chief of the Forest Service, blamed the 'natives' and their incendiary practices for the disappearance of the forest and the resulting climatic desiccation and degradation. $\mathrm{He}$ promoted extremely repressive policies and ridiculed the compromising colonial administration. The administration's views reflect this harder anti-fire line (even if field officers were still more pragmatic). Governor Hugues Berthier stated in 1929 that the goal of colonial agrarian policy was to move people out of the hills and mountains, stop shifting cultivation, and to institute a modern agricultural regime. ${ }^{42}$ Tavy fires, he declared, were a nefarious practice that would destroy the forest and ruin the country.

As a result, the 1930 Forest Decree significantly tightened regulations for forest exploitation. ${ }^{43}$ Tavy in forestland was simply illegal, as were all fires within 500 meters of any forest. The decree prohibited bushfires and prairie fires in non-forest lands, except when authorized by the governor's delegated authorities. It also legislated a more severe repression of infractions, increased the powers of forest agents, and reinforced punitive measures.

The 1930 decree set the tone for the following three decades. It was strengthened through amendments in 1937 and 1941, tightening the rules and broadening enforcement measures. ${ }^{44}$ However, the repressive legislative record masks continued debate in which fire use was defended. ${ }^{45}$ These debates hint at a recognition of the different logics of the concurrent pyric phases - the use of fire for agricultural or pastoral activities, versus the need to modernize agriculture and conserve nature through fire suppression. For instance, Governor Léon Cayla (1930-1939), echoing his predecessors, suggested that Madagascar was (still) in a transition to modern pasture maintenance (mowing, seeding), and thus that pasture fires had to be tolerated, while Governor Armand Annet (1940-1942) likewise asked districts to designate pasture areas where regulated fire could be permitted. ${ }^{46}$ 


\section{Towards a compromise: $1940 \mathrm{~s}-1960 \mathrm{~s}$}

The Second World War and the 1947 anti-colonial uprising led to a change in the emphasis. It was increasingly recognized, in some circles at least, that a number of 'pyric phases' were clashing. Farmers and herders continued burning while the modernizing colonial state sought to promote economic growth and rational (non-fire) exploitation on the one hand, and nature conservation (without fire) on the other. Unsurprisingly, during the 1947 rebellion, foresters - who represented the government's anti-fire activities - were a prominent target of violence. Many forestry posts were destroyed, forest plantations were burned, and a massive increase in fires and tavy was noted. ${ }^{47}$

In the 1950s, the administration harshly suppressed political activity and concentrated on economic development. Enforcement of fire-related infractions was relatively effective. Foresters received bonuses for successful citations, military patrols made tours of the countryside, fines were collected, and permits duly issued. New rules prohibited grazing in pastures burned without authorization, and prohibited cultivation in cut or burned state forests, giving the Forest Service a better means to enforce illegal burns. ${ }^{48}$

Fire policies were actively discussed. On the one side, hardliners including prominent botanists, Forest Service chiefs, and rangeland ecologists pushed for fire exclusion for economic and environmental reasons. ${ }^{49}$ These opinions were strengthened by botanist André Aubréville, influential head of the French colonial forest service, who strongly argued for forest protection by fire exclusion. ${ }^{50}$ In opposition, several fire-tolerance advocates emerged. They included district administrators, some range specialists, and anthropological and geographical researchers. ${ }^{51}$

The fact that French rule after 1947 was more tenuous, and the appearance of new voices for fire tolerance, led to a slight softening of the repressive regime against fires. Fire came to be seen as a 'necessary evil' and several ideas emerged. ${ }^{52}$ The first, not particularly new idea was to delimit areas where fires could be authorized. The second was that of legalizing counterseason fires or early fires, which would remove accumulated fuel but run a lesser danger of total combustion, escape from control, and subsequent soil and forest damage. ${ }^{53}$ A third new idea related to tavy. While the government had always pushed farmers to engage in irrigated rice cultivation, it had never helped them do so, so the Forest Service began investing in building small irrigation dams and canals and in instructing farmers on different techniques for soil conservation and intensive cultivation. A final idea was the use of pre-emptive controlled fires to reduce wildfire danger (this had some uptake across Africa, but never took hold in Madagascar).

Madagascar regained its independence on 26 June 26 1960, and within less than four months the new country had written its own fire laws. ${ }^{54}$ Ordonnance 60-127 differed from colonial laws in two significant ways: it contained no general ban on fires, and it was the first to clearly distinguish between different types of fire and set different policies for each. Fires for clearing forest for cultivation, i.e. tavy, were declared illegal in all state forests, and required authorization elsewhere, restricted to flat lands or the lower thirds of hills. Fires in permanent crop fields or along field edges were allowed at all times outside of forests. Pasture fires were allowed in officially delimited zones during the rainy season, and could 'exceptionally' be authorized at other times. Finally, wildfires burning without control or limits, in any type of vegetation, without any economic utility, were always illegal. 
This legislation was considerably more realistic than colonial legislation, as it recognized the utility of fire as a tool. However, it was still framed within an official position that highlighted fire as a hazard and a negative change agent causing environmental degradation. Its moderate view is reflected in publications of the time by sociologists and rangeland specialists. ${ }^{55}$ The effect of the legislation is hard to determine. Pasture fire and tavy authorizations were given in certain areas throughout this period, but the actual number of fires likely far outstripped the authorizations. From the farmer's point of view, the necessity to get authorizations for burning often involved prohibitive bureaucracy. Enforcement of fire infractions continued. ${ }^{56}$

\section{Resurgent fire exclusion for nature conservation, 1969 to present}

The exclusion of fire for nature conservation - a normative type of pyric phase that was aspired to but not often implemented - regained dominance in Madagascar in the late 1960s and remains dominant until today. This phase predominantly sees fire as a problematic change agent, sometimes as a hazard, and downplays any aspect of fire's useful role as a tool.

From the late 1960 s, fires were at the top of the national agenda. ${ }^{57}$ Several drought years and incendiary fire seasons caught the attention of President Philibert Tsiranana (1960-1972). His Conseil de Cabinet immediately banned all fires, and a high-level Interministerial Commission for the Fight Against Bushfires was convened. Concurrently, Madagascar became increasingly concerned with nature conservation. In 1970, the government hosted an international conference on conservation. Scientist after scientist condemned the degradation caused by tavy and pasture fires. ${ }^{58}$ All this attention on fires resulted in three new themes. First, the primary approach that was proposed - after legislative changes were abandoned was public awareness through an expensive propaganda campaign. Second, there were repeated attempts to make rural communities responsible for fire management, so that by 1971 there were five thousand 'anti-fire committees' created - at least on paper. ${ }^{59}$ Third, for the first time, the use of heavy machinery for fire fighting was proposed. ${ }^{60}$

Despite the regime changes during the revolutionary period of 1972-1975, and the supposedly populist dictatorship that followed, the anti-fire agenda intensified. ${ }^{61} \mathrm{New}$ decrees strengthened the rules for enforcement of illegal fires, by 1977 even making them capital offences. These 'brutal' rules hardly helped, as cattle raisers and forest farmers felt attacked by the unfair legislation ${ }^{62}$, and as the administration largely failed to enforce them. ${ }^{63}$ Anti-fire programs and reports proliferated. From 1976 to 1979, the government spent 40 to 90 million Malagasy francs per year on an anti-fire program of propaganda, field enforcement tours, and fire fighting machinery. ${ }^{64}$ In his 1980 New Year speech, President Didier Ratsiraka spoke of the need to fight without fail for the complete eradication of bush fires. This led to another Interministerial Commission, which criticized the apathy, laziness, and pyromania of the rural populations, grudgingly recognized the reasons behind the uses of fire, and paved the way for a seven year Opération Danga focused on awareness and enforcement. ${ }^{65}$

From the early 1980s, however, Madagascar's economy sank into turmoil, and the attention of most state agents turned away from fire. Despite the repressive laws and anti-fire programs, enforcement became more and more inconsistent. From an average of over 1,000 infractions per year between 1969 and 1975, the mid-1980s only saw 200 to 300 infractions per year. At the same time, district Forest Service offices continued to authorize pasture fires as demanded by cattle raisers. Authorizations were given for 150,000 to 850,000 hectares of fire each year, 
in the 1970s, and this system persisted to some extent into the 1980s. Politicians bent to the wishes of their constituencies, and repression was in name only. ${ }^{66}$

In the mid to late 1980s, the momentum for conservation lost since the 1970 conference resumed. Environmental concerns and activities boomed, yet the government was financially and politically paralysed. Fires were denounced with renewed vigour. In 1984, the country adopted a National Strategy for Conservation and Development. A year later, it convened a second international conference on conservation to discuss the implementation of the Strategy and to showcase the Malagasy environment. Diverse programs were initiated as a result centred on conservation, forest management, and environmental awareness, funded by the World Bank, bilateral donors, WWF, and UNESCO. These were succeeded by an ambitious 15 to 20 year Environmental Action Plan, launched in 1990 under the leadership of the World Bank. With initial funding commitments of over $\$ 100$ million, the Plan included a wide variety of programs designed to protect biodiversity, stop environmental degradation, and establish the institutional structures necessary for environmental monitoring and management. ${ }^{67}$

The situation on the ground in this period was a strong contrast to the grand ideas, intentions, and programs launched at the national and international level. The economic crisis and IMF austerity measures of the mid-1980s had paralysed the nation, and political unrest in 1991 and 1992, including a six-month general strike, led to the first of a number of tumultuous regime changes in the two decades that followed. As far as fires, the rules had not changed, yet fires burned more or less uncontrolled and enforcement lagged. As unpaid or striking government agents became less motivated to do their work, the rural population largely ignored the requirements and stopped seeking authorizations. ${ }^{68}$

From the mid-1990s, the government and foreign donors opened a new chapter in the history of fire politics, seeking to reconcile environmental goals and poorly functioning regulations through community-based resource management. Legislation passed in 1996 allowed for the transfer of resource management responsibilities and rights to community-based associations, and could, in theory, allow for community-based fire management. ${ }^{69}$ However, the contracts for local management had to conform to existing legislation, to Forest Service enforcement of that legislation (it had, for instance, ceased giving fire permits in 1990), and to the dominant discourse that saw fire as a hazardous change agent. As a result, local management contracts were more successful in managing forests than in addressing fire. ${ }^{70}$

From the mid-1990s, the first glimmers of a new 'pyric phase' also appeared. This could be characterised by the expression 'fire for ecosystem management', or the recognition - belated and incomplete on the Great Red Island - that fire is an integral component of many ecosystems. This approach, used for instance in park or forest management in South Africa, Australia, and the United States, sees fire as a useful tool, but for certain ecosystem management goals, not specifically for human utilitarian use. ${ }^{71}$ It also tends to recognize, and circumscribe if appropriate, fire's potential to be a hazard and a change agent. ${ }^{72}$ In a way, this pyric phase is a new, human-piloted version of the 'natural biospheric fire' pyric phase that existed before human settlement. Or it is a post-modern nature conservation pyric phase. In Madagascar, it has been recognized by scientists and managers working in specific conservation landscapes that fire plays a particular role in maintaining certain types of biodiversity, including orchids in the montane prairie of Andringitra, or the grasslands of Sakaraha. ${ }^{73}$ Yet such recognition remains rare. 
The above initiatives, which gently poked holes at different aspects of the government's strong fire exclusion approach, were further marginalized with the regime change in 2002. The goal-driven government of Marc Ravalomanana revitalized a top-down attitude of stopping all fires. Incentives were added to the rules and fines: municipal budgets depended on their fire-stopping performance. Satellite based fire monitoring was provided by foreign conservationists, ${ }^{74}$ and some high-profile cases of illegal slash-and-burn fires resulted in strict jail sentences. This strictness may, among a number of other factors, have contributed to the general concern over Ravalomanana's rule that led to his overthrow in 2009. In the years since, however, the fragile 'transitional' government of Andry Rajoelina has not fundamentally changed the emphasis on fire first and foremost as an undesirable change agent to the environment, second as a hazard to economic assets and production, both ahead of any recognition of fire as a useful tool.

\section{Conclusion}

In Madagascar's turbulent landscape of cyclones, droughts, floods, and political unrest, bushfires rank low as a priority for officials and agencies engaged in disaster risk management. It ranks very high, however, for environmental managers and conservationists seeking to preserve the highly valued native biodiversity of the island. That is, bushfire, while clearly a hazard at times for certain physical assets, rarely takes on disastrous proportions. However, attention focuses on it as a change agent leading to deforestation and habitat modification. Meanwhile, its use as a tool for pastoralists, farmers, and other land managers is largely relegated to an afterthought necessitated through political compromise.

In the end, it is important to recognize that fire is multivalent, ambiguous, and flexible. Malagasy villagers know this. One day in 1998, I walked with four boys in the hills above their highland village. In response to a bothersome swarm of little black flies, one of the boys lit the grass adjacent to the path, and we all stood in the fly-repelling smoke. As the grass was still green, it burned poorly, and soon all three boys were busy lighting little fires, laughing and chatting. One schoolboy chastised his brother 'hey, don't burn too much, the mayor might see us'. He continued, with a hint of irony, 'look, it's burning, we're destroying the environment!' Fire is both human and natural, it is both useful and problematic. Traditional farmers in Madagascar, as in the rest of the world, have dealt with fire's multiple meanings and manifestations for centuries - using fire yet fearing it, keeping it at bay yet taking advantage of it. Successive governments in Madagascar have misunderstood peasant burning practices, criminalizing a practice important to peasant livelihoods and landscape management due to their concerns about fire as a dangerous hazard and environmental change agent. Yet the limited resources of the state, the vast terrain, the inevitability of fire in wet-dry landscapes, and the inherent trump card held by those who want to burn allowed peasants to continue to light fires despite decades of bans, restrictions, fines, and anti-fire speeches. On the ground, the pastoral and agricultural pyric phases continue to trump, in most places, the fire exclusion pyric phases associated with modern economies and nature conservation. And the perception of fire as hazard always plays second fiddle to its utility as a tool for rural farmers and its threat as a change agent to conservationists. The hazard of fire to human life and property in Madagascar is punctual, localized, and a relatively small price to bear - when viewed at an aggregate level - compared to its benefits in agropastoral land management. For conservationists, fire matters less as a natural hazard to humans, but more as a hazard to nature, an instrument of habitat conversion. As the population continues to grow and the island modernizes, it remains to be seen what sorts of ambiguous, multivalent, and flexible fire regimes emerge in the future. 


\section{Bibliography}

Abe, Yoshio. 'Ancien Mode de Subsistence Pratiqué sur les Hautes Terres Centrales de Madagascar.' Asie du Sud-Est et Monde Insulindien 8, no. 3-4 (1977): 79-98.

Andriamampionona, A. 'Les Feux de Brousse dans la Région de l'Itasy.' Antananarivo: FAO/PNUD/MAG/88.032, 1992.

anon. 'Les Feux De Brousse.' Bulletin Economique, Madagascar et Dépendences 4, no. 1ere trimestre (1904): 25-9.

Ballet, Jérôme, and Mahefasoa Randrianalijaona, eds. Vulnérabilité, Insécurité Alimentaire et Environnement à Madagascar. Paris: L'Harmattan, 2011.

Bergeret, Anne. 'Discours et Politiques Forestières Coloniales en Afrique et à Madagascar.' Revue Français d'Histoire d'Outre-Mer 79, no. 298 (1993): 23-47.

Bird, Douglas W., Rebecca Bliege Bird, and Christopher H. Parker. 'Aboriginal Burning Regimes and Hunting Strategies in Australia's Western Desert.' Human Ecology 33, no. 4 (2005): 443-64.

Bosser, J. 'Les Pâturages Naturels de Madagascar.' Mémoires de l'Institut Scientifique de Madagascar Série B, V, (1954): 65-77.

Bowman, David M. J. S., Jennifer K. Balch, Paulo Artaxo, William J. Bond, Mark A. Cochrane, Carla M. D'Antonio, Ruth DeFries, Fay H. Johnston, Jon E. Keeley, Meg A. Krawchuk, Christian A. Kull, Michelle Mack, Max A. Moritz, Stephen J. Pyne, Christopher I. Roos, Andrew C. Scott, Navjot S. Sodhi, and Thomas W. Swetnam. 'The Human Dimension of Fire Regimes on Earth.' Journal of Biogeography 38, (2011): 2223-36.

Brand, Jürg. 'Das Agro-Ökologische System am Ostabhang Madagaskars: Ressourcen- und Nutzungsdynamik unter Brandrodung.' Dissertation, Universität Bern, 1998.

Brown, Mervyn. A History of Madagascar. London: Damien Tunnacliffe, 1995.

Burney, David A., Guy S. Robinson, and Lisa Pigott Burney. 'Sporormiella and the Late Holocene Extinctions in Madagascar.' PNAS 100, no. 19 (2003): 10800-805.

Burney, David A., Lida Pigott Burney, Laurie R. Godfrey, William L. Jungers, Steven M. Goodman, Henry T. Wright, and A. J. Timothy Jull. 'A Chronology for Late Prehistoric Madagascar.' Journal of Human Evolution 47, no. 1 (2004): 25-63.

Cori, Gilles, and Pierre Trama. Types d'Élevage et de Vie Rurale à Madagascar, Travaux et Documents de Géographie Tropical No. 37. Bordeaux: Centre d'Etudes de Géographie Tropicale, CNRS, 1979.

Coulaud, Daniel. Les Zafimaniry: Un Groupe Ethnique De Madagascar À La Poursuite De La Forêt. Antananarivo: Fanontam-Boky Malagasy, 1973.

Dewar, Robert E., and David Burney. 'Recent Research in the Paleoecology of the Highlands of Madagascar and Its Implications for Prehistory.' Taloha 12, (1994): 79-88.

Dewar, Robert E., Chantal Radimilahy, Henry T. Wright, Zenobia Jacobs, Gwendolyn O. Kelly, and Francesco Berna. 'Stone Tools and Foraging in Northern Madagascar Challenge Holocene Extinction Models.' PNAS 110, no. 31 (2013): 12583-88.

Dez, Jacques. 'Les Feux de Végétation: Aperçus Psycho-Sociologiques.' Bulletin de Madagascar 247, (1966): 1211-29.

Dez, Jacques. 'La Limitation des Feux de Végétation.' Terre Malgache 4, (1968): 97-124.

Donque, Gérald. 'Les Cyclones Tropicaux des Mers Malgaches.' Madagascar Revue de Géographie 27, (1975): 9-63.

Einrem, Johannes. Gjennem Grønne Briller. Vol. 1, Samlede Verker. Bergen: A. S. Lunde, 1912 (1936).

Eriksen, Christine. 'Why do they Burn the 'Bush'? Fire, Rural Livelihoods, and Conservation in Zambia.' Geographical Journal 173, no. 3 (2007): 242-56.

Fanony, Fulgence. 'Un Modèle de Stratégie de Conservation de la Forêt À Madagascar. 
L'exemple d'Andrianampoinimerina.' In Environnement et Gestion des Ressources Naturelles dans la Zone Africaine de l'Océan Indien, edited by Michel Maldague, Kabala Matuka and Roland Albignac, 349-52. Paris: Unesco, 1989.

Geoffroy, M. 'Les Feux de Brousse' Bulletin Economique, Madagascar 52, no. Mars 1931 (1931): 79-82.

Gilibert, J., P. Dubois, P. Granier, P. Grenier, and H. Serres. 'Lutte Contre les Feux Sauvages dans une Exploitation de Ranching.' Bulletin de Madagascar 24, no. 329 (1974): 46580 .

Gillson, Lindsey, and Katherine J. Willis. "as Earth's Testimonies Tell': Wilderness Conservation in a Changing World.' Ecology Letters 7, no. 10 (2004): 990-98.

Granier, P., and H. Serres. 'A Propos de L'incidence des Feux de Brousse sur l'Évolution des Pâturages.' Bulletin de Madagascar 16, no. 243 (1966): 789-91.

Heim, Roger. 'L'État Actuel des Dévastations Forestières à Madagascar.' Revue de Botanique Appliquée et d'Agriculture Tropicale 15, (1935): 418-26.

Humbert, H. 'Principaux Aspects de la Végétation à Madagascar. La Destruction d'une Flore Insulaire par le Feu.' Mémoires de l'Académie Malgache Fascicule V, (1927).

Humbert, Henri. 'La Dégradation des Sols à Madagascar.' Mémoires de l'Institut de Recherche Scientifique de Madagascar D1, no. 1 (1949): 33-52.

IUCN. Comptes Rendus de la Conférence Internationale sur la Conservation de la Nature et de ses Ressources à Madagascar, Tananarive 7-11 Octobre, 1970, Publications UICN Nouvelle Série, Document Supplémentaire No. 36. Morges, Switzerland: IUCN, 1972.

Jarosz, Lucy. 'Defining Deforestation in Madagascar.' In Liberation Ecologies, edited by Richard Peet and Michael Watts, 148-64. London: Routledge, 1996.

Kaufmann, Jeffrey C., and Sylvestre Tsirahamba. 'Forests and Thorns: Conditions of Change Affecting Mahafale Pastoralists in Southwestern Madagascar.' Conservation and Society 4, no. 2 (2006): 231-61.

Keeley, Jon E., Gregory H. Aplet, N. L. Christensen, S. G. Conard, E. A. Johnson, P. N. Omi, D. L. Peterson, and Thomas W. Swetnam. Ecological Foundations for Fire Management in North American Forest and Shrubland Ecosystems, Portland: USDA Forest Service, 2009.

Klein, Jørgen, Betrand Réau, and Mary Edwards. 'Zebu Landscapes: Conservation and Cattle in Madagascar.' In Greening the Great Red Island: Madagascar in Nature and Culture, edited by Jeffrey C. Kaufmann, 157-78. Pretoria: Africa Institute of South Africa, 2008.

Kull, Christian A. 'The Evolution of Conservation Efforts in Madagascar.' International Environmental Affairs 8, no. 1 (1996): 50-86.

Kull, Christian A. Isle of Fire: The Political Ecology of Landscape Burning in Madagascar. Chicago: University of Chicago Press, 2004.

Kull, Christian A. 'Saving Land with a Spade: Human Landscape Transformations in the Madagascar Highlands.' In Greening the Great Red Island: Madagascar in Nature and Culture, edited by Jeffrey C. Kaufmann, 113-35. Pretoria: Africa Institute of South Africa, 2008.

Kull, Christian A. 'The Roots, Persistence, and Character of Madagascar's Conservation Boom.' In Conservation and Environmental Management in Madagascar, edited by Ivan R. Scales. London: Earthscan, 2014.

Kull, Christian A., and Paul Laris. 'Fire Ecology and Fire Politics in Mali and Madagascar.' In Tropical Fire Ecology: Climate Change, Land Use, and Ecosystem Dynamics, edited by Mark A. Cochrane, 171-226. Heidelberg, Germany: Springer-Praxis, 2009.

Laney, Rheyna M. 'Disaggregating Induced Intensification for Land-Change Analysis: A Case Study from Madagascar.' Annals of the Association of American Geographers 
92, no. 4 (2002): 702-26.

Laris, Paul. 'Burning the Seasonal Mosaic: Preventative Burning Strategies in the Wooded Savanna of Southern Mali.' Human Ecology 30, no. 2 (2002): 155-86.

Lavauden, L. 'Histoire de la Législation et de L'administration Forestière À Madagascar.' Revue des Eaux et Forêts 72, (1934): 949-60.

Olson, Sherry. 'Environments as Shock Absorbers, Examples from Madagascar.' Environmental Review 12, no. 4 (1988): 61-80.

Perrier de la Bâthie, Henri. 'La Végétation Malgache.' Annales du Musée Colonial de Marseille Sér. 3, v. 9, (1921): 1-266.

Pollini, Jacques. 'The Difficult Reconciliation of Conservation and Development Objectives: The Case of the Malagasy Environmental Action Plan.' Human Organization 70, no. 1 (2011): 74-87.

Pyne, Stephen J. Vestal Fire. Seattle: University of Washington Press, 1997.

Pyne, Stephen J. Fire: A Brief History. Seattle: University of Washington Press, 2001.

Pyne, Stephen J. 'The Human Geography of Fire: A Research Agenda.' Progress in Human Geography 33, no. 4 (2009): 443-46.

Rabetaliana, Hanta, Michel Randriambololona, and Peter Schachenmann. 'The Andringitra National Park in Madagascar.' Unasylva 50, no. 196 (1999): 25-30.

Rakatonindrina, Raymond. 'Les grands problèmes actuels de la conservation des écosystèmes: défrichement et feux de brousse.' In Environnement et Gestion des Ressources Naturelles dans la Zone Africaine de l'Océan Indien, edited by M. Maldague, K. Matuka and R. Albignac, 111-22. Paris: Unesco, 1989.

Rakotoarimanana, Vonjison, and Michel Grouzis. 'Influence du Feu et du Pâturage sur la Richesse et la Diversité Floristiques d'une Savane à Heteropogon Contortus du SudOuest de Madagascar.' Candollea 61, no. 1 (2006): 167-88.

Ranaivoarivelo, Nivo, and Pierre Milleville. 'Exploitation Pastorale des Savanes de la Région De Sakaraha (Sud-Ouest De Madagascar).' In Sociétés Paysannes, Transitions Agraires et Dynamiques Écologiques dans le Sud-Ouest de Madagascar, edited by Samuel Razanaka, Michel Grouzis, Pierre Milleville, Bernard Moizo and Christine Aubry, 181-97. Antananarivo: CNRE \& IRD, 2001.

RDM. 'Rapport Du Groupe Interministériel D'etudes Sur Les Feux De Brousse.' Antananarivo: Repoblika Demokratika Malagasy, 1980.

Scales, Ivan R. 'Farming at the Forest Frontier: Land Use and Landscape Change in Western Madagascar, 1896-2005.' Environment and History 17, (2011): 499-524.

Sivaramakrishnan, K. 'The Politics of Fire and Forest Regeneration in Colonial Bengal.' Environment and History 2, no. 2 (1996): 145-94.

\section{Notes}

${ }^{1}$ Donque (1975), Olson (1988) Ballet \& Randrianalijaona (2011). It is striking how little published research exists on natural hazards and disasters in Madagascar.

${ }^{2}$ Kull (2004)

${ }^{3}$ For Indonesia see Fowler (2013), for Western Australia see Bird et al. (2005), for Africa see

Eriksen (2007), Laris (2002).

${ }^{4}$ Sivaramakrishnan (1996), Pyne (1997), Kull and Laris (2009).

${ }^{5}$ Einrem (1912).

${ }^{6}$ Archives Nationales de Madagascar (hereafter ANM). Folder Vice Présidence 850, subfolder 'Situation des feux de brousse 1969-1971'.

${ }^{7}$ Express de Madagascar (17 June 2013, http://www.lexpressmada.com/vohemarmadagascar/44084-la-moitie-d-un-village-rasee-par-les-flammes.html). 
8 ANM, folder Vice Présidence 850, subfolder 'Conference international...' To my knowledge, his is the only year for which such a summary has been made. As it has a political goal, there may be some strategic conflation of bushfires with house fires.

${ }^{9}$ Bowman et al. (2011); c.f. Pyne (2001, 2009) and Kull (2008).

${ }^{10}$ Significant passages of the text on the history of government attempts to manage fire are based on Chapter 7 in Kull (2004) and the references and archival sources cited therein.

${ }^{11}$ Burney et al. (2004), Dewar and Burney (1994).

${ }^{12}$ Dewar et al. (2013).

${ }^{13}$ Bowman et al. (2011).

${ }^{14}$ Bird et al. (2005).

${ }^{15}$ Burney et al. (2004), Dewar et al. (2013).

${ }^{16}$ Burney et al. (2004), Kull (2008).

17 Pyne (2001), Laris (2002), Fowler (2013).

${ }^{18}$ Coulaud (1973), Brand (1998), Laney (1999), Kull (2004).

${ }^{19}$ Multiple interviews with farmers, 1998-2001. See Kull (2004).

${ }^{20}$ Coulaud (1973), Humbert (1927), Scales (2011).

${ }^{21}$ Abe (1977).

${ }^{22}$ Burney et al. (2003, 2004).

${ }^{23}$ Klein et al. (2008).

${ }^{24}$ Cori and Trama (1979).

${ }^{25}$ Kull (2004).

${ }^{26}$ J.-P. Raison, pers. comm.; field interviews by author, August 1999.

${ }^{27}$ Geoffroy (1931).

${ }^{28}$ Ranaivoarivelo and Milleville (2001), (Kaufman and Tsirahamba 2006).

${ }^{29}$ Kull (2004).

${ }^{30}$ These include Andrianampoinimerina's edicts and the Code of 305 Articles, discussed in Kull (2004), where I also mention a possible exception to the lack of regulation (p. 207 $\mathrm{n} 2)$.

${ }^{31}$ Brown (1995).

${ }^{32}$ Dez (1968)

${ }^{33}$ Journal Officiel de Madagascar (hereafter JOM), 15 Jan 1898.

${ }^{34}$ JOM, 17 April 1900.

35 anon (1904).

36 JOM, 30 Mar 1904. For further details, see Kull (2004, p. 208)

${ }^{37}$ JOM, 9 Mar 1907, 12 Jun 1909, 10 May 1913, 9 Oct 1915 and 20 Nov 1920; ANM D81s and D196; Lavauden (1934); Dez (1968). For details, see Kull (2004, p.210-215).

${ }^{38}$ Jarosz (1996), Kull (2004).

${ }^{39}$ Kull (2004).

${ }^{40}$ Lavauden (1934), Jarosz (1996), Kull (2004).

${ }^{41}$ Perrier (1921, p. 4), Humbert (1927).

${ }^{42}$ JOM, 9 Feb. 1929.

${ }^{43}$ JOM, 22 Nov. 1930.

${ }^{44}$ JOM, 13 July 1937 and 20 Dec 1941; AOM fn-sg-mad 353/948; See Kull (2004, p. 222)

${ }^{45}$ e.g. Geoffroy (1931), Lavauden (1934), Heim (1935), and Archives d'Outre Mer (Aix-enProvence; hereafter AOM) mad-ggm-2/D/19bis/6, p. xiv. See Kull (2004, p. 220).

${ }^{46}$ JOM, 2 July 1938, 6 Dec 1941.

${ }^{47}$ Jarosz (1996), Kull (2004).

${ }^{48}$ Brown (1995), Dez (1968), Kull (2004). 
${ }^{49}$ For instance: botanist Humbert (1949), Forest Service chief Bégué, and rangeland ecologist Bosser (1954).

${ }^{50}$ Bergeret (1993).

${ }^{51}$ Kull (2004).

${ }^{52}$ Dez (1968), Kull (2004).

${ }^{53}$ Unfortunately for its champions, early burns were never a perfect solution, as they were often very difficult to ignite in the rainy season, and their effects on pasture were not the same as dry season fires (Dez 1968).

${ }^{54}$ JOM, 15 Oct 1960.

${ }^{55}$ Sociologists: Dez (1966, 1968); rangeland specialists: Granier and Serres (1966), Gilibert et al. (1974).

${ }^{56}$ Rakatonindrina (1989); interviews with farmers and foresters, 1998-1999 (see Kull 2004).

${ }^{57}$ ANM Vice-Presidence folders 831, 840, 844, 850, 851.

${ }^{58}$ IUCN (1972), Kull (1996).

${ }^{59}$ DEF Annual Report, 1971. See Kull (2004, p. 235).

${ }^{60} \mathrm{RDM}$ (1980).

${ }^{61}$ Andriamampionona (1992); JOM, 30 Sep 1972, 2 Dec 1972, 1 Nov 1975, and 27 Aug 1976; see Kull (2004, p236).

${ }^{62}$ Cori and Trama (1979, p. 58).

${ }^{63}$ Fanony (1989).

${ }^{64} \mathrm{RDM}(1980)$.

${ }^{65} \mathrm{RDM}(1980)$.

${ }^{66}$ Rakatonindrina (1989), Kull (2004).

${ }^{67}$ Kull (1996, 2014), Pollini (2011).

${ }^{68}$ Multiple interviews, foresters and farmers, 1998-2001 (see Kull 2004, p. 240-1).

${ }^{69} \mathrm{JOM}, 14$ Oct 1996.

${ }^{70}$ Kull (2004).

${ }^{71}$ Gillson and Willis (2004).

${ }^{72}$ Keeley et al. (2011).

${ }^{73}$ Rabetaliana et al. (1999), Rakotoarimanana and Grouzis (2006).

${ }^{74}$ The satellite data comes from NASA (earthdata.nasa.gov/data/near-real-time-data/firms), and is available via free subscription at the Conservation International website (firealerts.conservation.org/fas/home.do) (sites last accessed 25 Aug. 2013). 